\title{
HANTBUCH FAR BIBLIOTEKN - PODRĘCZNIK DLA BIBLIOTEK ŻYDOWSKICH Z OKRESU MIĘDZYWOJENNEGO
}

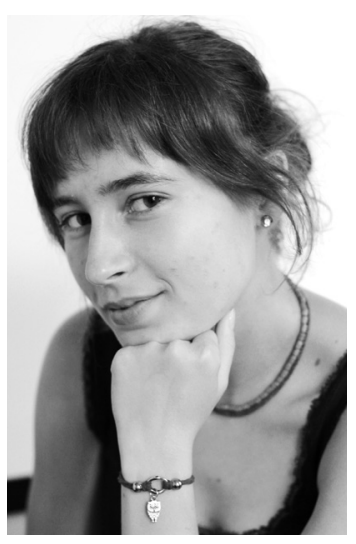

Monika Biesaga, doktorantka na Wydziale Historycznym Uniwersytetu Jagiellońskiego. Przygotowuje rozprawę doktorską na temat żydowskich bibliotek publicznych w międzywojennej Polsce. Ukończyła studia magisterskie na kierunku informacja naukowa i bibliotekoznawstwo (Uniwersytet Jagielloński, 2012) oraz judaistyka (Uniwersytet Jagielloński, 2013). Stypendystka m.in. Israeli Government, Rothschild Foundation (HaNadiv) Europe oraz Center for Urban History of East Central Europe. Obecnie pracuje na stanowisku Reference Specialist w British Library w Londynie.

SŁOWA KLUCZOWE: Biblioteki żydowskie. Biblioteki robotnicze. Podręczniki dla bibliotek - Polska - 1918-1939.

ABSTRAKT: Teza/cel artykułu - W artykule omówiony został prawdopodobnie jedyny podręcznik dla bibliotek żydowskich, który został opublikowany w międzywojennej Polsce. Hantbuch far bibliotekn (pol. Podręcznik dla bibliotek) został napisany w języku jidysz przez I. Rauchfleischa oraz dr. L. Weissa i wydany przez Towarzystwo Kursów Wieczorowych dla Robotników (TKWdR) w 1929 r. w Warszawie. W zamyśle autorów przeznaczony miał być dla żydowskich bibliotek robotniczych. Metody badań - W artykule dokonano analizy zawartości podręcznika, przedstawiając pokrótce treść każdego rozdziału. Wyniki i wnioski - Przeprowadzona analiza treści podręcznika pozwoliła stwierdzić, że wprawdzie była to publikacja przeznaczona dla bibliotek robotniczych, ale służyć mogła również jako poradnik dla każdego typu biblioteki, gdyż zawiera wiele ogólnych wskazówek i informacji, a także obszerny aneks z gotowymi wzorami dokumentów.

Zawód bibliotekarza w dzisiejszym tego słowa znaczeniu zaczął się kształtować w XVIII w. Do tego czasu mówimy raczej o profesji lub zajęciu, którym 
najczęściej zajmowały się osoby posiadające wykształcenie humanistyczne. W 1876 r. w Stanach Zjednoczonych powstało pierwsze stowarzyszenie bibliotekarzy na świecie - American Library Association (ALA) oraz zaczęto wydawać fachowe czasopismo „American Library Journal” (w 1877 r. tytuł zmieniono na „Library Journal”). W $1887 \mathrm{r}$. Melvil Dewey założył pierwszą na świecie szkołę bibliotekarską - School of Library Economy (Thomison, 1978, p. 1, 10, 30). Zawód bibliotekarza formował się na ziemiach polskich w okresie zaborów i ostatecznego kształtu nabrał dopiero w 20-leciu międzywojennym (Włodarczyk, 1988; 1990). W tym okresie głównymi pomocami metodologicznymi były czasopisma fachowe, a w procesie kształcenia bibliotekarzy korzystano głównie z prac częściowo omawiających zagadnienia z zakresu nauki o bibliografii, bibliotece i książce (np. Przewodnika dla korzystajacych z bibliotek Józefa Grycza, czy Życia ksiażki Jana Muszkowskiego) albo prac zagranicznych uczonych (na język polski został przetłumaczony w 1938 r. Praktyczny podręcznik bibliotekarza Leo Crozeta) (Gaca-Dąbrowska, 1983, s. 171-172). Organizowano także okresowe kursy doszkalające. Planowano wydanie podręcznika, ale pomysł ten do wybuchu II wojny światowej pozostał niezrealizowany. Jedyną publikacją o charakterze podręcznika, przeznaczoną jednak tylko dla bibliotek wojskowych, jest wydany w $1929 \mathrm{r}$. Podręcznik bibliotekarski dla kierowników bibliotek wojskowych autorstwa Mariana Łodyńskiego, Jana Niezgody i Wiktora Kochanowskiego.

Z podobnymi problemami natury metodologicznej borykały się w okresie międzywojennym również biblioteki żydowskie, które wówczas przeżywały swój największy rozwój. Według ogólnopolskiego spisu bibliotek przeprowadzonego w 1929 r. w Polsce znajdowało się 748 bibliotek żydowskich, co stanowiło 8,8\% wszystkich placówek bibliotecznych. Była to trzecia największa sieć biblioteczna po polskiej (6289 placówek - 73,7\%) i ukraińskiej (1214 placówek - 14,4\%). Jeśli jednak przyjrzeć się liczbie książek, która w bibliotekach żydowskich wynosiła ponad 860 tys., daje to drugi pod względem wielkości księgozbiór, zaraz po polskim (biblioteki ukraińskie, choć przeważające liczebnie posiadały w swych zbiorach nieco ponad 265 tys., czyli 4,3\%) (Bibljoteki..., 1932, s. XXV).

Wiele bibliotek żydowskich w tym okresie zakładanych było przez organizacje i stowarzyszenia, które rekrutowały bibliotekarzy spośród swoich członków. Często były to osoby przypadkowe, które pracowały w bibliotece jako wolontariusze, bez odpowiedniego przygotowania metodologicznego. Na tym właśnie polu, jedną z pierwszych inicjatyw podjęło Stowarzyszenie Kultur-Lige ${ }^{1}$, które w 1925 r. rozpoczęło wydawanie miesięcznika recen-

\footnotetext{
${ }^{1}$ Stowarzyszenie Kultur-Lige (właśc. Liga Kultury Proletariackiej; także: Liga Kultury Żydowskiej) - organizacja kulturalno-oświatowa założona w Kijowie w 1917 r., związana z kołami jidyszystycznymi oraz z Bundem. W Polsce organizacja została zawiązana w 1922 (bądź 1921) i zarejestrowana w 1926 r. Kultur-Lige miała swoje oddziały terenowe w całej Polsce, zwłaszcza tam gdzie liczniejszy był proletariat żydowski.
} 
zyjnego w języku jidysz pt. „Buch un Lezer”2 (Książka i Czytelnik). W sumie ukazały się jednak tylko trzy numery. Kolejną inicjatywą Kultur-Lige było wydanie w 1929 r. katalogu wzorcowego dla bibliotek ludowych w języku jidysz pt. Dos Jidisz Buch (Książka Żydowska) oraz w języku polskim pt. Ksiażka polska w bibliotece żydowskiej. Ponadto, informacje o bibliotekach i książkach można był także znaleźć na łamach czasopism - żydowskich i polskich. Przykładowo, w latach 1922-1929 Kultur-Lige wydawało dwumiesięcznik w języku jidysz pt. „Bicher-Welt” (Świat Książek), w którym obok kwestii związanych z literaturą jidysz ukazywał się dodatek poświęcony bibliotekom żydowskim. Magazynem o podobnej tematyce było „Literarisze Bleter", wychodzące w latach 1924-39. Również tu przez pewien czas ukazywała się rubryka poświęcona bibliotekom żydowskim pt. „Bibliotekn-Centr ba der Kultur-Lige". Do tego należy dodać także kilka artykułów, które ukazywały się na łamach prasy polskiej, m.in. Hermana Kruka, który publikował w „Przeglądzie Bibliotecznym” (Kruk, 1934), czy w „Bibliotekarzu” (Kruk, 1937-38). W 1928 r. Kultur-Lige zorganizowało pierwszy kurs biblioteczny.

Spośród tych inicjatyw ciekawą i dotąd niewspominaną w źródłach polskich $^{3}$ pozycją jest Hantbuch far bibliotekn (Podręcznik dla bibliotek) - prawdopodobnie pierwszy i jedyny podręcznik dla bibliotek żydowskich, autorstwa I. Rauchfleischa oraz dr. L. Weissa, wydany w Warszawie w 1929 r. przez Towarzystwo Kursów Wieczorowych dla Robotników.

\section{ŻYDOWSKIE BIBLIOTEKI ROBOTNICZE W MIĘDZYWOJENNEJ POLSCE}

Towarzystwo Kursów Wieczorowych dla Robotników (jid. Gezelszaft Ownt Kursn far Arbeter, dalej: TKWdR) zostało założone w 1916 r. w kilku większych miastach polskich, m.in. w Warszawie i w Łodzi. W połowie lat 20. stało się jedną z czołowych żydowskich placówek kulturalnych dla klasy robotniczej w Polsce (Garncarska-Kadary, 2001, s. 214). Poprzez organizację kursów, odczytów, wykładów, koncertów, przedstawień w języku polskim i jidysz, rozpowszechnianie wśród robotników podręczników, wydawanie własnych publikacji, zakładanie bibliotek, czytelni i kół sportowych TKWdR realizowało swoje cele statutowe, które zakładały "szerzenie powszechnej i zawodowej oświaty wśród robotników", a także rozwój ich poczucia estetycznego i wzbogacenie wiadomości (Statut..., [1926], s. 1).

Centrala bibliotek TKWdR mieściła się w Warszawie. W 1928 r. pod jej zarządem znajdowało się 95\% wszystkich bibliotek TKWdR. Przeciętnie

\footnotetext{
${ }^{2} \mathrm{~W}$ odniesieniu do języka jidysz $\mathrm{w}$ artykule zastosowano uwspółcześnioną i uproszczoną transkrypcję polską.

${ }^{3}$ Brak informacji o tej pozycji m.in. w rozdziale poświęconym bibliotekom w książce: R. Żebrowski; Z. Borzymińska (1993). Po-lin: kultura Żydów polskich w XX wieku, Warszawa: Amarant.
} 
księgozbiory liczyły ok. 4-5 tys. książek. Najmniejsze placówki posiadały ok. 250 tytułów. W każdej bibliotece znajdowała się czytelnia czasopism, a największą frekwencję odnotowywano w godzinach wieczornych. Pod koniec lat 20. XX w. wzorcową biblioteką stała się warszawska instytucja, rozlokowana w kilku lokalach, i przez to określana potocznie jako „wędrowna biblioteka". Zorganizowano przy niej kursy dla bibliotekarzy oraz instruktorn-center (z jid. centrum instruktażu). Zdecydowano również o utworzeniu czytelń przy innych placówkach utrzymywanych przez TKWdR, a więc przy szkołach wieczorowych, klubach sportowych, czy organizacjach młodzieżowych, tak by książka mogła dotrzeć wszędzie tam, gdzie gromadzili się członkowie TKWdR. W 1925 r. w warszawskich szkołach wieczorowych TKWdR uczyło się ok. 200 osób. Księgozbiór biblioteczny wynosił ok. 1000 pozycji, w tym 535 w jidysz. W ciągu roku szkolnego 124 stałych członków biblioteki wypożyczyło 2685 pozycji, co daje 22 przeczytane książki na jednego czytelnika. Biorąc pod uwagę, że rok szkolny trwał od 6 do 8 miesięcy, to średnia liczba książek wypożyczanych w jednym miesiącu przez każdego czytelnika wynosiła 3 egzemplarze, a więc można powiedzieć, że poziom czytelnictwa był stosunkowo wysoki (Garncarska-Kadary 1995, s. 309-311).

Według wspomnianego już ogólnopolskiego spisu bibliotek z 1929 r. w tym czasie w Polsce znajdowało się 85 bibliotek TKWdR. Najwięcej z nich - 22 mieściło się na terenie województwa lubelskiego, 17 placówek znajdowało się w województwie mazowieckim, 14 w łódzkim oraz $12 \mathrm{w}$ kieleckim. Najmniej bibliotek znajdowało się na terenie dawnej Galicji (w województwie krakowskim zarejestrowano zaledwie 3 placówki, $2 \mathrm{w}$ tarnopolskim oraz po jednej w województwach lwowskim i stanisławowskim). Żadnej biblioteki nie odnotowano wówczas w 4 województwach: poznańskim, pomorskim, śląskim i wileńskim. Wielkość księgozbiorów bibliotek TKWdR była zróżnicowana. Na wsiach i w mniejszych miejscowościach księgozbiory liczyły od kilkudziesięciu do kilkuset tomów, natomiast $\mathrm{w}$ większych miastach ich rozmiary wyniosły kilka tysięcy, np. w Warszawie - 7100, w Krakowie - 6900, w Nowym Sączu - 4250, w Łodzi - 4230, w Kaliszu - 3900, czy we Włocławku - 3698. Większość z nich miała charakter publiczny, co oznacza, że dostęp do nich był powszechny i korzystać z nich mogli nie tylko członkowie towarzystwa. Zdarzało się tak zwłaszcza w przypadku mniejszych miejscowości, gdzie bibliotek było niewiele. Udostępniano wówczas zbiory wszystkim zainteresowanym, najczęściej wprowadzając dodatkową opłatę dla osób nienależących do towarzystwa. Niektóre biblioteki posiadały oddzielne lokum, ale większość z nich mieściła się w lokalach organizacji. Ułatwiało to zapewne szybki dostęp do księgozbioru członkom towarzystwa i redukowało koszty dodatkowego wynajmu sali. Bibliotekom TKWdR najczęściej nadawano imię Dow Bera Borochowa (1881-1917), rosyjskiego polityka i filozofa żydowskiego pocho- 
dzenia, jednego z czołowych ideologów partii Poalej Syjon (Borzymińska \& Żebrowski, red., 2003, s. 221-222).

Sieć bibliotek dla robotników TKWdR nie była jedyna. Również inne żydowskie organizacje robotnicze, związki zawodowe i partie robotnicze w międzywojennej Polsce starały się tworzyć własne instytucje kultury, które miały promować i zaspokajać potrzeby czytelnicze ${ }^{4}$. Przykładowo, najliczniejsza i najsilniejsza żydowska partia robotnicza w Polsce Bund (jid. Związek) do 1939 r. założyła 264 biblioteki dla robotników, choć w większości były to niewielkie placówki ze skromnym księgozbiorem w języku jidysz (Rose, p. 181). Obok dużych sieci bibliotecznych, wymienić można też szereg mniejszych placówek, m.in. bibliotekę Związku Żydowskich Robotników „Oświata” w Podhajcach (1927), bibliotekę Związku Rzemieślników Żydowskich w Dubnie (1927), Bibliotekę Żydowskich Robotników w Terespolu (1928), bibliotekę Związku Zawodowego Żydowskich Robotników Odzieżowych w Sarnach (1928), czy powstałą jeszcze w czasie I wojny światowej bibliotekę Związku Zawodowego Nauczycielstwa Żydowskiego Ziemi Wileńskiej w Wilnie (1915) (Bibljoteki..., 1932). Natomiast największą żydowską biblioteką robotniczą w międzywojennej Polsce była mieszcząca się w Warszawie Biblioteka im. Bronisława Grossera ${ }^{5}$, założona w 1915 r. przez działaczy związanych z Bundem. W 1930 r. została przejęta przez Kultur-Lige, która zamierzała uczynić z niej centralną wzorcową bibliotekę robotniczą. W 1934 r. jej księgozbiór liczył ok. 20 tys. publikacji i ok. 1,8 tys. czytelników (Borzymińska \& Żebrowski, red., 2003, s. 188-189). W 1936 r. jej zbiory sięgały już 30 tys. pozycji (Bieńkowska, red., 2000, s. 287). Zasłużoną postacią dla rozwoju tej biblioteki był jej wieloletni dyrektor - Herman Kruk (Gruszka, 2010). Przyczynił się on nie tylko do rozwoju biblioteki im. Grossera, ale także dzięki swoim publikacjom i aktywnej postawie, zaliczany jest do grona pionierów żydowskiego bibliotekarstwa w Polsce.

\section{HANTBUCH FAR BIBLIOTEKN - OMÓWIENIE TREŚCI PODRĘCZNIKA}

Hantbuch far bibliotekn to licząca 73 strony publikacja w języku jidysz, choć $\mathrm{w}$ tytule zawiera słowo podręcznik, ma raczej charakter poradnika. Autorzy nie zamieścili w niej przypisów ani bibliografii, a więc trudno stwierdzić, z jakich pomocy naukowych korzystali przy jej pisaniu. Zagadnienia poruszane w tej publikacji dotyczą przede wszystkim kwestii związanych

\footnotetext{
${ }^{4}$ Geneza żydowskich bibliotek robotniczych (jid. arbeter bibliotek) sięga lat 70. XIX w. i podobnie jak bibliotek polskich, również związana jest z terenem zaboru rosyjskiego. Prawdopodobnie pierwszą z nich była założona w 1872 r. przez Jakowa Abba Finkelsteina nielegalna biblioteka przy Seminarium Rabinicznym w Wilnie.

${ }^{5}$ Bronisław Grosser (1883-1912) - publicysta i działacz socjalistyczny żydowskiego pochodzenia. Był propagatorem idei autonomii kulturalno-narodowej w Bundzie.
} 
z wewnętrzną organizacją biblioteki. Znajdują się tu szczegółowe opisy poszczególnych czynności (dotyczące np. rozmieszczenia księgozbioru, prowadzenia ksiąg inwentarzowych itp.), często opatrzone dodatkowymi wyjaśnieniami i przykładami. Jej niewątpliwą zaletą jest obszerny aneks, zawierający gotowe wzory dokumentów, w tym m.in. szablon karty książki, karty czytelnika, legitymacji czytelnika, ankiety, regulaminu bibliotecznego, raportów kasowych, zestawień rachunkowych. Mimo iż na wstępie książki znajdują się odniesienia do aktualnej sytuacji żydowskich bibliotek robotniczych w Polsce, w pozostałej części podręcznika znajdujemy wiele ogólnych wskazówek i objaśnień, z których korzystać mogły wszystkie placówki biblioteczne, nie tylko te przeznaczone dla robotników. Także sam tytuł publikacji jest ogólny i nie precyzuje żadnego typu bibliotek ${ }^{6}$.

Podręcznik został podzielony na 14 rozdziałów:

1. Nasze biblioteki

2. Zadania bibliotekarza

3. Lokal i wyposażenie

4. Zakup książek

5. Oprawa książek

6. Konserwacja książek

7. Rozmieszczenie księgozbioru

8. Księga inwentarzowa i karty katalogowe

9. Katalog dla czytelników

10. Legitymacje, karty czytelników, regulamin i karty zamówień

11. Statystyka biblioteczna

12. Księgowość biblioteki

13. Gazetka biblioteczna

14. Jak założyć i zalegalizować bibliotekę? (Rauchfleisch \& Weiss, 1929, s. [3])

Na wstępie publikacji autorzy podkreślają rolę i miejsce biblioteki w życiu

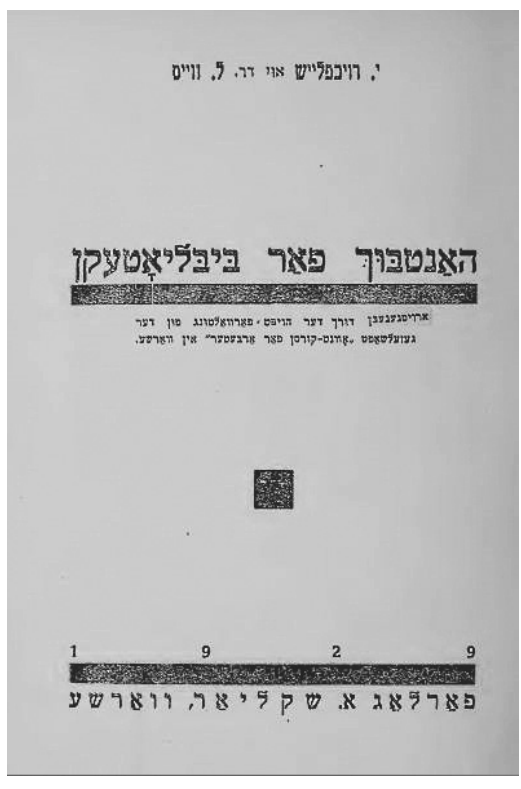

I. Rauchfleisch, L. Weiss: Hantbuch far bibliotekn. Warszawa 1929. robotników. Obok szkół, kursów i uniwersytetów ludowych stanowią one jedne z ważniejszych instytucji kultury. Dbałość o nie powinna leżeć przede wszystkim w gestii czytelników. Natomiast niską frekwencję czytelniczą oraz ogólnie zły stan bibliotek autorzy tłumaczą niewykwalifikowaniem kadry, która nie potrafi odpowiednio zachęcić czytelnika do korzystania z jej zasobów. Stwierdzają oni nawet, że żaden z bibliotekarzy nie jest odpowiednio przygotowany do wypełniania swojego zawodu. Ten stan po części wynika z braku odpowiednich kursów, podręcz-

${ }^{6}$ Wszystkie tłumaczenia z języka jidysz są dokonane przez autorkę. 
ników, specjalistycznych czasopism na rynku polskim, które byłyby pomocne w rozwijaniu umiejętności i podnoszeniu kwalifikacji bibliotekarzy, zwłaszcza żydowskich. Sprawia to, że ich rola w bibliotekach ogranicza się wyłącznie do udostępniania zbiorów: „Nie wystarczy pomóc naszemu czytelnikowi w dostaniu książki, ale trzeba mu ją wskazać, nauczyć go ją czytać i rozumieć. A kto ma to uczynić? Bibliotekarz, który wie o wiele mniej od czytelnika? Dlatego nie ma się co dziwić, że liczba użytkowników bibliotek jest bardzo mała w porównaniu z ogólną liczbą robotników" (Rauchfleisch \& Weiss, 1929, s. 7).

Trzeba tu podkreślić, iż sama grupa czytelników wymagała dostosowania się bibliotekarza do specyficznych warunków pracy. Robotnicy byli często osobami słabo wykształconymi, którzy ukończyli kilka klas szkoły podstawowej i posiadali jedynie umiejętność czytania, ale brakowało im zamiłowania do książki. Dlatego zdaniem autorów podręcznika pierwszoplanowym zadaniem bibliotekarzy powinno być nabycie zdolności właściwego podejścia do czytelnika, rozpoznania jego potrzeb czytelniczych oraz wyrobienia w nim odpowiednich nawyków i chęci do samodzielnego poszerzania wiedzy. Bibliotekarz miał być nauczycielem czytelnika i mediatorem pomiędzy nim a książką: „on [bibliotekarz] jest spiritas novens [sic!] biblioteki, motorem, sternikiem. On jest jak oficer w armii, który walczy o wiedzę" (Rauchfleisch \& Weiss, 1929, s. 9-10). W tym celu - radzili autorzy podręcznika - przynajmniej raz w tygodniu powinno się organizować spotkania z czytelnikami oraz pogadanki na temat literatury (np. na temat gatunków literackich) (Rauchfleisch \& Weiss, 1929, s. 11).

W tej kwestii podobne zdanie miał również dyrektor największej biblioteki robotniczej w międzywojennej Polsce - Herman Kruk, pisząc: „,Dzisiejszy bibliotekarz winien myśleć o tym, w jaki sposób pozyskać najszersze rzesze dla jednego powszechnie dostępnego źródła wiedzy - dla biblioteki. Bibliotekarz powinien szukać czytelnika, sprowadzić go do biblioteki, musi umieć obudzić w nim zainteresowanie dla książki. Biblioteka ma więc doniosłą rolę społeczno-wychowawczą do spełnienia" (Kruk, 1937-38, s. 55).

Do podstawowych zadań bibliotekarza należały więc następujące czynności:

- dobór literatury;

- katalogowanie książek;

- udzielanie porad i wskazówek czytelnikom;

- poszerzenia horyzontów myślowych czytelników poprzez organizację pogadanek, kół, wykładów etc.;

- pobudzanie w czytelnikach chęci do odkrywania różnych dziedzin wiedzy;

- cykliczne prowadzenie statystyk bibliotecznych (Rauchfleisch \& Weiss, 1929, s. 12-13).

Obok postaci bibliotekarza - jako równie ważną kwestię - wskazywano otoczenie, które powinno być tak urządzone i zorganizowane, aby stanowić miejsce przyjazne dla czytelnika: „Lokal [biblioteczny] - makom kodesz [hebr. 
miejsce święte] w świecie czytelnika" (Rauchfleisch \& Weiss, 1929, s. 16). Dlatego każda biblioteka powinna składać się przynajmniej z dwóch pomieszczeń: zaplecza bibliotecznego, gdzie zamawia się i wypożycza książki oraz czytelni z katalogiem i księgozbiorem podręcznym. Stoliki w czytelni należy wyposażyć w lampkę oraz przybory do pisania (atrament i pióro). W tym samym lokalu co biblioteka nie powinna mieścić się żadna inna instytucja (Rauchfleisch \& Weiss, 1929, s. 14-16).

Księgozbiór biblioteczny podzielony powinien być na 4 działy:

- nauki społeczne;

- nauki przyrodnicze;

- beletrystyka;

- literatura dla dzieci i młodzieży.

Jeśli w zasobach znajdują się książki w językach obcych, to wskazane jest utworzenie dla nich osobnego miejsca. W obrębie każdego z działów, w podręczniku proponowany jest układ alfabetyczny lub systematyczny (Rauchfleisch \& Weiss, 1929, s. 23-24).

Kolejną ważną kwestią jest dobór i zakup nowych książek. Bibliotekarze zwykle kierując się skromnymi środkami finansowymi wybierają najtańsze dostępne pozycje albo dążą do kompletowania wszystkich dzieł danego pisarza. Żadna z tych metod nie jest jednak aprobowana przez autorów podręcznika, gdyż w przypadku bibliotek robotniczych mamy do czynienia ze specyficznym typem czytelnika. Selekcja materiałów nie jest więc prostym zadaniem, zwłaszcza ze względu na brak pomocy w tym zakresie (brak katalogów i bibliografii zalecających). Dlatego bibliotekarze powinni kierować się publikacjami, których temat pasować będzie do działów, na które podzielony został księgozbiór biblioteczny, a więc w tym wypadku: nauki społeczne, nauki przyrodnicze, beletrystyka, literatura dla dzieci i młodzieży. Zaleca się także, by bibliotekarze utrzymywali kontakt z wydawnictwami i korzystali z katalogów wydawniczych przy doborze literatury (Rauchfleisch \& Weiss, 1929, s. 17-19).

Każdy nowy nabytek, który trafia na półkę biblioteczna, musi zostać odnotowany w księdze inwentarzowej. Przy opisie każdej publikacji podawać należy następujące dane: sygnaturę książki nadaną w bibliotece, nazwisko i imię autora, tytuł, tom/część, liczbę stron, wydawnictwo, miejsce wydania, rok wydania, cenę oraz uwagi, a następnie sporządzać kartę książki (jid. buch-karte), z osobną rubryką na numer czytelnika tak, by można było później łatwo zidentyfikować osobę, która wypożyczyła daną książkę (Rauchfleisch \& Weiss, 1929, s. 27-28).

By ułatwić czytelnikowi orientację w księgozbiorze bibliotecznym autorzy podręcznika radzą utworzenie katalogu systematycznego zbiorów według 4 głównych działów bibliotecznych (w obrębie każdego działu stosować należało układ alfabetyczny według nazwisk autorów, a jeśli w bibliotece znajdowało się kilka książek tego samego autora, to ich tytuły układać rów- 
nież według kolejności alfabetycznej, nie chronologicznej). Każda pozycja zaopatrzona powinna być w numer katalogowy książki. Tak przygotowany katalog mógł mieć dwie postacie: książkową lub kartkową. Katalog w formie książki był rekomendowany dla bibliotek posiadających więcej niż tysiąc książek, natomiast dla małych placówek wystarczający wydawał się katalog kartkowy. Zaletą tego drugiego była możliwość dodawania kart nowych nabytków, bez potrzeby burzenia przyjętego wcześniej układu. Jeśli biblioteka miała taką możliwość, to jako idealny wskazywano stan posiadania obu typów katalogów (Rauchfleisch \& Weiss, 1929, s. 29-30).

Aby móc skorzystać ze zbiorów, każdy czytelnik musi posiadać własną legitymację oraz kartę czytelnika, która zawiera następujące dane: nazwisko i imię, adres, wiek, zatrudnienie, miejsce pracy, datę zapisu do biblioteki, wysokość kaucji wpłaconej przez czytelnika, datę, numer paragonu z podaną sumą numer (wypożyczonej) książki, datę wypożyczenia i zwrotu książki. Szczegółowe zasady odnoszące się do udostępniania księgozbioru zawarte powinny być w wewnętrznym regulaminie biblioteki, któremu autorzy podręcznika przypisali doniosłe miano „konstytucji bibliotecznej” (Rauchfleisch \& Weiss, 1929, s. 33-34).

By móc stwierdzić, czy biblioteka funkcjonuje w sposób wydajny i spełniający potrzeby czytelnika, każda placówka powinna prowadzić 3 rodzaje statystyk: czytelników, książek oraz finansów. W przypadku badań czytelnictwa pod uwagę należy brać wiek czytelnika, jego płeć, wykształcenie, wykonywany zawód, przynależność do stowarzyszeń lub innych organizacji. Statystyka książek ma natomiast dać odpowiedź co do liczby wypożyczeń danej pozycji w obrębie każdego z działów głównych księgozbioru. Ponadto, pomocne we właściwym rozwijaniu działalności bibliotecznej mogą być również ankiety przeprowadzane wśród czytelników, raporty (dzienne, miesięczne i roczne), zestawienia zakupów oraz wypożyczeń książek (według miesięcy). Przykładowy kwestionariusz ankiety, który został podany $\mathrm{w}$ aneksie podręcznika, zawiera pytania o wiek czytelnika, jego wykształcenie, członkostwo w organizacjach, znajomość języka jidysz (w mowie i piśmie), stopień znajomości innych języków oraz regulaminu bibliotecznego. Raporty natomiast, poprzez ukazanie dynamiki wypożyczeń w określonych odstępach czasowych, mają ułatwić kontrolę ruchu bibliotecznego oraz ułatwić rozplanowanie prac i wskazanie dalszych kierunków rozwoju biblioteki (Rauchfleisch \& Weiss, 1929, s. 37-46).

W końcu w każdej bibliotece powinno prowadzić się 3 rodzaje ksiąg finansowych: księgę czytelników, księgę kasową księgę rachunkową. W księdze czytelników rejestruje się wysokość kaucji oraz abonamentów wniesionych przez każdego czytelnika, który po uiszczeniu opłat otrzymać powinien odpowiedni kwit poświadczający wpłatę. W księdze kasowej znaleźć się winny dane dotyczące przychodów i wydatków na rzecz biblioteki (na koniec każdego miesiąca sporządza się raport podsumowujący), a w księdze 
rachunkowej długi, jakie posiada biblioteka oraz spis dłużników biblioteki (Rauchfleisch \& Weiss, 1929, s. 47-58).

Dodatkowo w czytelniach rekomendowano tworzenie gazetek bibliotecznych, przypominających o ważnych rocznicach, wydarzeniach i postaciach. By ułatwić czytelnikowi poszerzanie wiedzy na wskazany temat, pod częścią informacyjną znaleźć się powinna lista proponowanych lektur dotyczących danego zagadnienia, dostępnych aktualnie w bibliotece (wraz z podaniem sygnatur) (Rauchfleisch \& Weiss, 1929, s. 59-60).

Podsumowując, Hantbuch far bibliotekn wydany przez Towarzystwo Kursów Wieczorowych dla Robotników był unikatowym, a nawet pionierskim wydawnictwem w okresie 20-lecia międzywojennego i to zarówno na polu bibliotekarstwa żydowskiego, jak i polskiego, które nie doczekało się wydania własnego podręcznika. Jak wynika z omówienia treści podręcznika, większość zagadnień w nich poruszanych ma charakter ogólny. Nawet podział księgozbioru wydaje się uniwersalny i nie zawiera żadnych szczególnych odniesień do preferencji czytelniczych robotników. Ze względu na dość uniwersalną treść oraz praktyczny charakter, który przejawia się w prostym języku, licznych przykładach i gotowych wzorach, zasięg tej publikacji mógł być ogólnopolski i obejmować wszystkie biblioteki, nie tylko te należące do sieci TKWdR, jednak o jej dystrybucji i wykorzystaniu nic bliższego nie wiemy.

\section{BIBLIOGRAFIA}

Bibljoteki oświatowe: spis na dzień 1 stycznia 1930 roku oraz tablice statystyczne (1932). Warszawa; Lwów: Ministerstwo Wyznań Religijnych i Oświecenia Publicznego.

Bieńkowska, Barbara, red. (2000). Informator o stratach bibliotek i księgozbiorów domowych na terytoriach polskich okupowanych w latach 1939-1945 (bez Ziem Wschodnich). Poznań: Ministerstwo Kultury i Dziedzictwa Narodowego, Biuro Pełnomocnika Rządu do Spraw Polskiego Dziedzictwa Kulturalnego za Granicą.

Borzymińska, Zofia; Żebrowski, Rafał, red. (2003). Polski słownik judaistyczny: dzieje, kultura, religia, ludzie (2003). Warszawa: Prószyński i S-ka.

Gaca-Dąbrowska, Zofia (1983). Bibliotekarstwo II Rzeczypospolitej: zarys problemów organizacyjnych i badawczych. Wrocław: Wydaw. Uniwersytetu Wrocławskiego.

Garncarska-Kadary, Bina (1995). Di Linke Poalej-Syjon in Pojlin biz Der Cwejter Welt-Milchome. Tel Awiw: Farlag I. L. Perec.

Garncarska-Kadary, Bina (2001). Żydowska ludność pracująca w Polsce: 1918-1939. Warszawa: Żydowski Instytut Historyczny.

Gruszka, Zbigniew (2010). Herman Kruk (1897-1944) jako organizator i dyrektor biblioteki getta wileńskiego. Szkic do obrazu bibliotekarstwa żydowskiego w Polsce. Acta Universitatis Lodziensis. Folia Librorum, nr 16, s. 171-182.

Kruk, Herman (1934). Żydowskie bibliotekarstwo w Polsce. Przeglad Biblioteczny, z. 1, s. 1-9. Kruk, Herman (1937-38). Metody pracy biblioteki im. Bronisława Grossera w Warszawie. Bibliotekarz, nr 3-4, R. IX, s. 54-61. 
Łodyński, Marian (1929). Podręcznik bibliotekarski dla kierowników bibliotek wojskowych. Warszawa: Wojskowy Instytut Naukowo-Wydawniczy.

Rauchfleisch, I.; Weiss, L. (1929). Hantbuch far bibliotekn. Warszawa: Nakładem A. Szklara.

Rose, Jonathan (2001). Workers' Library. In: International Dictionary of Library Histories, Vol.

1. Ed. by David H. Stam. Chicago: Fitzroy Dearborn Publishers, pp. 179-182.

Statut Towarzystwa Kursów Wieczornych dla Robotników w Warszawie [1926], Warszawa: Towarzystwo Kursów Wieczornych dla Robotników.

Thomison, Dennis (1978). A history of the American Library Association 1876-1972, Chicago: American Library Association.

Włodarczyk, Jerzy (1990). Kształtowanie się zawodu bibliotekarskiego na ziemiach polskich w okresie zaborów. Łódź: Wydaw. Uniwersytetu Łódzkiego.

Włodarczyk, Jerzy (1988). Bibliotekarze w Polsce okresu międzywojennego. Łódź: Wydaw. Uniwersytetu Łódzkiego.

Żebrowski, Rafał; Borzymińska, Zofia (1993). Po-lin: kultura Żydów polskich w XX wieku, Warszawa: Amarant.

Artykut wptynąt do Redakcji 13 marca 2017 r.

MONIKA BIESAGA

Institute of Jewish Studies

Jagiellonian University

e-mail: monikabiesaga@gmail.com

\section{HANTBUCH FAR BIBLIOTEKN - A HANDBOOK FOR JEWISH LIBRARIES OF THE INTERWAR PERIOD}

KEYWORDS: Jewish libraries. Workers' libraries. Handbooks for libraries. Poland. 1918-1939.

ABSTRACT: Thesis/Objective - The article is a discussion of, most probably, the only handbook for Jewish libraries published in Poland in the interwar period. Hantbuch far bibliotekn (Handbook for libraries) was written in Yiddish by I. Rauchfleisch and dr. L. Weiss and published by Towarzystwo Kursów Wieczornych dla Robotników (TKWdR, The Association of the Evening Studies for Workers) in 1929 in Warsaw. The authors designed their publication as a handbook for Jewish libraries for workers. Research methods - The content of each chapter of the handbook was analyzed and presented. Results and conclusions - The analysis of the handbook content proved that the handbook was addressed to the libraries for workers but it could be used by any library as it contained numerous guidelines and information of general nature as well as a large supplement with templates of various types of documents. 